\title{
Word etymology in monolingual and bilingual dictionaries: lexicographers' versus EFL learners' perspectives
}

Zahra Awad

Department of Linguistics and Phonetics, University of Jordan, Jordan

https://doi.org/10.36505/ExLing-2006/01/0013/000013

\begin{abstract}
This paper deals with the treatment of word etymology in monolingual and bilingual dictionaries. It also investigates EFL learners' attitudes towards the importance of etymology for understanding the meaning of the words they look up in dictionaries. The data were collected through tasks of looking up Arabic loan words in English in monolingual and bilingual dictionaries. The results indicate that most monolingual and bilingual dictionaries do not provide information on word etymology. They also show that most Arab EFL learners find etymology helpful in understanding the meaning of English words of Arabic origin.
\end{abstract}

\section{Introduction}

Since the late 17th century English general-purpose monolingual dictionaries have included information about the etymology of words (Stockwell \& Minkova, 2001). The origin of many English words is indicated as being French, Latin, Greek, German, Hindi and Arabic. There are perhaps as many as 10,000 English words derived from Arabic.

This study is an investigation of how English words of Arabic origin are dealt with in English monolingual dictionaries and English-Arabic bilingual dictionaries. It is also an attempt to find out how important EFL learners consider knowing the origin of such words in understanding their meaning.

\section{Methodology}

The study is based on the treatment of 10 Arabic loan words in English in 4 monolingual and 3 bilingual dictionaries. They were chosen from a list of such words given in Al-Mawrid Dictionary (1997). Their etymology was verified in the Dictionary of Words Origin (1975). The words were: massage, algebra, candy, chap, garble, shifty, syrup, safari, cumin, tariff.

The monolingual dictionaries used were: Oxford Advanced Learner's Dictionary (OALD) (1989), Longman Dictionary of Contemporary English (LDOCE) (1987), Merriam-Webster's Dictionary (WD) (1997) and the American Heritage Dictionary (AHD) (1991). The bilingual dictionaries

ExLing 2006: Proceedings of 1st Tutorial and Research Workshop on Experimental Linguistics, 28-30 August 2006, Athens, Greece 
used were: Al Mawrid Dictionary (1997) Dictionary, Atlas Encyclopaedic Dictionary (2005), and Al Mughni Al-Akbar Dictionary (1991).

The study is also based on analyzing Arab EFL learners' performance in two writing tasks and their responses to a questionnaire and in structured interviews. These learners were 200 second year students majoring in Applied English at the University of Jordan. They were taking a course on study skills which deals partly with using dictionaries.

The students were asked to look up the meaning of the target words in a monolingual dictionary, then in a bilingual one indicating their etymology if given and mention if that helped them in understanding the meaning of these words. After submitting each task, they were interviewed to verify their answers.

The questionnaire consisted of twelve questions dealing with the students' background information and their use of dictionaries. It was administered to the students after they performed the required tasks.

\section{Results and discussion}

The look ups of the target words indicated variations in the etymological information provided in the monolingual dictionaries as shown in Table I.

Table I. Availability of etymology in monolingual dictionaries.

\begin{tabular}{|l|l|l|l|l|l|}
\hline No. & Word & OALD & LDOCE & AHD & WD \\
\hline 1 & Algebra & X & X & $\sqrt{ }$ & $\sqrt{ }$ \\
\hline 2 & Candy & X & X & $\sqrt{ }$ & $\sqrt{ }$ \\
\hline 3 & Chap & X & X & X & X \\
\hline 4 & Cumin & X & X & X & X \\
\hline 5 & Garble & X & X & V & $\sqrt{ }$ \\
\hline 6 & Massage & X & X & $\sqrt{ }$ & $\sqrt{ }$ \\
\hline 7 & Safari & X & X & $\sqrt{ }$ & $\sqrt{ }$ \\
\hline 8 & Shifty & X & X & X & X \\
\hline 9 & Syrup & X & X & $\sqrt{ }$ & $\sqrt{ }$ \\
\hline 10 & Tariff & X & X & $\sqrt{ }$ & $\sqrt{ }$ \\
\hline
\end{tabular}

It is clear from Table I that WD and AHD provide the etymology for most of the words, while OALD and LDC do not.

The look ups of the words also indicated variations in the etymological information provided in the bilingual dictionaries, as shown in Table II. 
Table II. Availability of etymology in bilingual dictionaries.

\begin{tabular}{|l|l|l|l|l|}
\hline No. & Word & Atlas & Al-Mughni & Al-Mawrid \\
\hline 1 & Algebra & X & X & V \\
\hline 2 & Candy & X & X & V \\
\hline 3 & Chap & X & X & X \\
\hline 4 & Cumin & X & X & X \\
\hline 5 & Garble & X & X & V \\
\hline 6 & Massage & X & X & V \\
\hline 7 & Safari & X & X & V \\
\hline 8 & Shifty & X & X & X \\
\hline 9 & Syrup & X & X & V \\
\hline 10 & Tariff & X & X & V \\
\hline
\end{tabular}

It is obvious from Table II that Al-Mawrid provides the etymology for most of the words, while Atlas and Al-Mughni do not.

The analysis of the students' responses indicated variations in the students' attitude towards the importance of knowing the Arabic origin of the target words to understand their meaning, as illustrated in Table III below.

Table III: Students' attitudes towards word origin

\begin{tabular}{|l|l|}
\hline Easier with their origin & Percent \\
\hline Yes, always & 20.7 \\
\hline Yes, sometimes & 41.4 \\
\hline Yes, most of the time & 20.7 \\
\hline No & 13.8 \\
\hline No answer & 3.4 \\
\hline Total & 100.0 \\
\hline
\end{tabular}

Table III shows that most students considered knowing the Arabic origin of the target words important in order to understand them. For example, 20.7\% of them considered that always important, $20.7 \%$ thought it was important most of the time, and $41.4 \%$ considered it sometimes important. 


\section{Conclusion}

The results indicated that both English monolingual dictionaries and English-Arabic bilingual dictionaries vary in providing etymology information on Arabic loan words in English. They also show that most EFL dictionary users tend to consider knowing the etymology of such words important for understanding their meaning. It is recommended that compilers of both bilingual and monolingual dictionaries consider including the origin of Arabic loan words in English in their entries.

\section{References}

Abbas, S. (ed.) 2005. Atlas Encyclopaedic Dictionary. Amman, Atlas Global Center for Publishing and Distributing.

Al-Ba'alabki, M. 1998. Al-Mawrid : A Modern English - Arabic Dictionary. Beirut, Dar EL- Ilm Lil - Malayen.

Cowie, A.P. (ed.). 1989. Oxford Advanced Learner's Dictionary of Current English. Oxford: Oxford University Press.

De Vinne, P. B. 1991. The American Heritage Dictionary. Boston, Houghton Mifflin Company.

Karmi, H. 1991. Al-Mughni Al-Akbar (A dictionary of contemporary English). Beirut, Libraie du Liban.

Shipley, J. T. 1975. Dictionary of Words Origin. London: Philosophical library. URL http: // www.questia.com /

Stevens, Mark A. 1997. Merriam Webster's Collegiate Dictionary. Springfield : Merriam Webster, Incorporated.

Stockwell, R. and D. Minkova. 2001. English Words: History and Structure. Cambridge University Press.

Summers, D (ed.). 1987. Longman Dictionary of Contemporary English. England: Longman Group. 